\title{
Reasons for Optimism and the Tasks at Hand
}

\section{Positive Signs and Reasons for Hope}

The challenges and tasks facing African countries may seem daunting, but this does not warrant an overtly pessimistic judgement, as there are in fact positive aspects in the countries that when properly recognized and utilized can be instrumental in the development of the region. Africa's problems, which have been cited by so many, are exhaustive, but I have reason to be optimistic and believe that Africa can indeed succeed in transforming itself. Here I would like to explain why.

I can think of at least seven reasons to be positive. First of all, the root cause of underdevelopment of Sub-Saharan Africa is essentially a matter of 'intent' rather than being structural or environmental in nature. Second, there is a prevalence of openness and pragmatism in the region. Third, Africa's political, economic and social structures are not 'fixed', but dynamic. Fourth, there is great potential for development because of the 'cushions' they have: an abundance of land, including vast fertile soils, untapped natural resources and a growing young population that can be turned into 'assets'. Fifth, there have been so much disappointments and shortcomings that now the time is ripe 
for accepting the inevitability of 'change' and doing things differently on the part of Africans and the international development community alike. Sixth, an increasing number of Africans are beginning to understand that not only the world but also their sub-regions are becoming ever more competitive and that they need to develop competitiveness in order to survive and prosper. Seventh, there are a number of very positive traditions or customs conducive to development in Africa that have been overlooked, forgotten or underestimated, but which should be duly recognized or brought back into play.

Regarding the first question of intent, changing the mindset of the people is by no means easy and some say that it can be the most difficult thing to do. But when mindset change actually does occur, even partially and incrementally, it can unleash a powerful force that brings about changes beyond people's imagination. Mindset change is important not only for development but also for dealing with social problems like violence, killings and abuses that plague the people, because such problems cannot be resolved through law enforcement alone. If the mindset change of the individuals takes place collectively, its impact will be huge and can bring about a sea change. As much as there are aspirations for growth and prosperity in the region, there has to be an equal level of seriousness for mindset change.

I do not see Africa's development problem as a fundamentally structural one that cannot be overcome despite human efforts to do so. Africans are not subjected to perennial wars, natural disasters and diseases on a grand scale, although it tends to be big news when these do occur. Africa is a huge continent and except for some limited troublespots and isolated cases, the vast region is mostly calm, peaceful and stable. There is nothing that coercively suppresses the people from developing. Wars are man-made and epidemics are, strictly speaking, also man-made. To treat Africa differently from the rest of the world by depicting it as always being in a more adverse state than other regions is simply wrong. I have met so many locals who were very proud of their heritage, and some even suggested that Africa lags behind other regions because it is blessed with an overabundance of so many things.

What is also striking is that there is a genuine passion for education and learning among the populace. In every circumstance, education is 
the key and it will make all the difference. But apart from regular academic teaching, subjects on socialization or 'national ethics' should be newly introduced and pragmatic, vocational skills training must be expanded. In the end, Africans have to, and eventually will, come to terms with this critical matter of 'intent' because this is unavoidable, if not quintessential.

The second reason is closely related to the first one. I personally think that the most attractive and promising feature of the people in Sub-Saharan Africa is that they are predominantly open-minded and pragmatic, and not ideological, self-closing or dogmatic. In fact, I find virtually everyone-elites, intellectuals and the general populace-in the Sub-Saharan African region to be very receptive and friendly. Nearly all African countries are seen to pursue pro-development, pro-liberal market economy policies and want to very much enhance business in collaboration with foreign firms and partners. Religious extremists and terrorist organizations are mainly confined to Somalia and northern Nigeria. What is interesting, however, is that South Africa, which is economically the most advanced country in Sub-Saharan Africa, is perhaps the most ideologically charged nation in the region, mostly due to the legacy of apartheid.

Third, Africa's political, economic and social structures are not 'fixed', but are dynamic and still in the making. I think that many will agree that this is true, which is why I am rather optimistic about the future of Africa. I have a sense that in due course, Sub-Saharan African countries-and if not all of them, then at least an increasing number of them-will experience an 'awakening' with respect to their reality and will take charge of their destiny.

Fourth, Sub-Saharan Africa is promising in terms of its sheer size of the 'untouched' fertile land mass. It is also abundant in untapped natural resources and boasts a growing young population, which should be regarded as a potential asset rather than an economic and social burden. Some point out that the demographic dividend could be a huge advantage for Africa: 'You don't need to stay long in any African city to feel the entrepreneurial energy on the streets. For those of us who grew up on the continent, it is very much a fact of life. But for those visiting, perhaps for the first time, it can seem overwhelming. There is no 
single reason, of course, for this bustle and energy. But a big part of it comes from the fact that Africa has the youngest population of any continent.' ${ }^{1}$ It is a matter of how people perceive things and what choice of actions they take.

These are all valuable 'cushions' that Africa can take advantage of in the future exigencies of this world. Ironically, the uncertainties of the world like global climate change, shortage of foodstuffs, the impact of ageing society in industrialized countries, etc. may make Sub-Saharan Africa increasingly attractive. There is also a special 'affection' and eagerness on the part of international community to recognize its positive developments.

The fifth point I want to make is that now many people appear to be craving something new and different that can work. People are literally fed up with the rampancy of corruption, mismanagement, breach of laws, and irresponsible and immoral acts that mar the basic functioning of society and the state. In this respect, we should acknowledge that there is an apparent variance on this point across the African continent: at one end of spectrum, some countries are viewed in a positive light, giving rise to optimism, while at the other end, certain countries are suffering from prolonged crises involving unending internal conflict, destabilization and human suffering. Even within a country, the situation may vary depending on the region, but hopefully good practices will prevail and spread.

The sixth argument is that even in Sub-Saharan Africa, 'competition' has set in as a stark reality. By now, state leaders, elites and businessmen should know that economic performance or capacity is what matters. They are not only competing among themselves for foreign development assistance, but also-and more importantly-for trade, investment and tourism. Competitiveness is becoming a key word in Sub-Saharan Africa and there will be countries 'running away' and receiving increased recognition and opportunities, while others lag further behind. The pursuit of equality and welfare is like a double-edged sword for development: it can hurt if it is too little or too much. But the principal driver of economic growth is competition and comparative advantage. 
Lastly, Africans nations and donors alike should 'rediscover' the valuable 'gems' of Africa that have been underestimated. African people greatly value recognition, like earning academic certificates and degrees, and winning citations and awards. The sense of pride that I see in ordinary African people for being honoured for their achievements is immense. Another positive element is the tradition of community-based self-help work. In Uganda, this is called Bulungi Bwansi (for the good of the nation) and in Rwanda Umuganda (coming together for a common purpose), while in Burundi it is called Ibikorwa Rusangi. Many other countries, including Ethiopia, have similar traditions. In Uganda, the Bulungi Bwansi movement has weakened following the influx of foreign aid and the popularization of the 'welfare' policy of the government that exacerbated the dependency syndrome of the local populace. The situation is more or less the same in most other African countries.

It will not be difficult for devoted Africanists to soon recognize that 'Africa has rich, ancient traditions of what we call public work-self organized communal labours. These are crucial foundations for a democratic way of life that existed long before Europeans brought the term to the continent'. ${ }^{2}$ But many such traditional virtues have been neglected, discouraged or sabotaged with political intent by African rulers after independence. The unwholesome electoral democracy prevalent in the region is seen to have smothered the voluntarism that would have really empowered the people.

In any case, we should neither be naive and optimistic nor overly pessimistic and cynical. Only being truthful and candid about the problems will be of help. As the saying goes, 'truth will set you free'.

\section{The Task of the Donor Community}

What are the things that donors should do to improve the situation and the efficiency of aid? Compared to what African countries need to do, which are basically fundamental things, the tasks facing donors are more technical in nature, including features like coordination, 
know-how transfer, supervision, etc. But the reality obliges donors to not only carry out such technical tasks but also to constantly 'press' others, the aid-recipients, to do their necessary part as well. From the donor community's perspective, aids provided to African countries since their independence were not having desired outcomes and African countries needed to assume greater responsibility as aid recipients. The end of the Cold War brought about fundamental changes in international political dynamics and this lead to a basic change in donors' stance as well:

The 1990s was an era of the re-examination of aid's effectiveness and imposition of 'conditionality' with increased donor fatigue and call for good governance to root out corruption. Emphasis was also placed on reducing aid dependence as well as liberalization and privatization, while there was a resurgence of the poverty alleviation objective. ${ }^{3}$

As for the development doctrine in the 2000s, the development community ran out of 'big ideas'. Following the turn of the century, it seems that no one was confident to lay out a clear prescription in terms of theory and policy. Instead, the international community came up with action-oriented plans like the Millenium Development Goals (MDG), and the problem of aid fragmentation was seriously considered. Since the new millennium, while the Washington Consensus has been 'muted', there have been bits of everything without a clear aid policy-orientation.

Development paradigms before the MDGs lacked formal international agreement, but the MDGs emerged as the first ever of their kind in terms of their formality (although the agreement was incomplete) and specific action goals. The MDGs were mainly the outcome of the work by a small group within the OECD Development Assistance Committee (DAC) and UN Secretary General Kofi Annan's Millennium Declaration, which lacked the formal approval of the UN General Assembly. Hence, developing countries tended to view MDGs as part of the developed countries' agenda, but the SDGs were an outcome of much more broader deliberations and were formally adopted at the UN summit. Therefore, it can boast greater legitimacy in that both developed and developing countries can claim its ownership. ${ }^{4}$ 
Good governance is also rightfully stressed, as political stability and sound institutions are vital to sustainable growth. The need for industrialization and building infrastructure, and private sector participation in the funding for development, among other factors, are also underscored. On the other hand, the fact that SDGs have a very broad scope in terms of issue areas and items, and that these goals are designed to be taken up on a voluntary basis by the states will likely prompt both developing countries and developed countries to act in a discretionary and selective manner suited to their national interests. ${ }^{5}$

So, what should the task be for the donor community? First, the international community should take a long hard look at the reality and limitations of existing approaches, and realize the need to be more open-minded and creative about making improvements. Second, the donor community as a whole must forge closer collaboration, and where it is appropriate and possible to do so, should try to be less competitive and be more complementary.

We have seen the evolution of the aid doctrine since the 1950s. At the multilateral level, the aid doctrine and policies have been driven by developed countries through their organizations, namely the OECD DAC, along with the World Bank and IMF. While international organizations ensure the consistency, predictability and stability of international aid policies, as well as providing specialized or tailored assistance for a whole range of needs, bilateral donors are the major funders of international organizations and at the same time are their collaborative clients or partners on the ground.

Looking back, the MDGs were touted by the UN as 'the most successful anti-poverty movement in history' ${ }^{6}$ But it would be fair to say that the MDGs had limited success in terms of the overall development of Africa, as the goals were focused on poverty reduction and assistance for 'basic needs'. The lessons learnt are already incorporated to a certain extent in the action plans of the SDGs, and as this is the general framework of development at the global level, the UN is doing its fair share to spearhead this. But the UN cannot be guarantors of Africa's transformation, and it is only at the national level of African countries that the successful implementation of the SDGs can be achieved. 
While the donor community has inherent limitations, it also provides a meaningful support that we can call 'limited external governance'. To understand the value of this 'limited external governance', one only needs to think what would have happened if foreign aid personnelofficials, experts, workers and volunteers-were suddenly withdrawn or aid programmes were stopped. Hence, the basic challenge regarding aid is twofold: how to overcome dependency syndrome and how to improve the overall governance. And I think the theme of enhancing aid effectiveness captures both. But things have to change and can change for the better. One way to do this is by avoiding the 'Samaritan's dilemma'?

Aid can end up just as one-time transfers of wealth or can be 'wealth creating' if used properly. Therefore, the principle of 'rewards and punishments' should be applied and the tools of incentives and competition should be employed, along with consideration of the needs of African countries. Foreign aid should be value-adding and 'giving credit where it is due', 'reward based on merit' or 'effective resource reallocation' ought to be the catchphrases that donors should be honouring.

I have already mentioned that democracy and governance are basically an outcome of development rather than its precondition. Western countries were not democratized when they were industrializing, and the East Asian economies achieved rapid growth under authoritarian political regimes and imperfect governance. Of course, the better the governance, the better it will be for development. This is all the more true for Sub-Saharan African countries. Corruption, irregularities and political repression were also common in East Asian countries, nut Asian nations were much more development-oriented in terms of state leadership, policy focus and work ethics compared to African nations.

Countries that ranks high in terms of development in the region, such as Mauritius, Botswana, Namibia, Cape Verde, the Seychelles and South Africa, all boast high marks in governance and democracy. But needless to say, the ideal condition for developing countries will be to have both strong a work ethic and good governance. While it will be no easy feat to achieve both at the same time, if at least steady improvements can be made in these, the countries will no doubt make great progress. 
The vast majority of official development assistance (ODA) is provided by the OECD Development Assistance Committee (DAC) members. The DAC is comprised of 29 countries, plus the EU, of which all except for two (Japan and South Korea) are Western countries. In 2016, the OECD DAC's net ODA totalled USD 142.62 billion, which represents an $8.9 \%$ increase compared to 2015; the top five donors were the US (USD 335.9 billion), Germany (USD 246.7 billion), the UK (USD 180.1 billion), Japan (USD 103.7 billion) and France (USD 95.0 billion); the DAC has provided USD 267.4 billion to Africa, of which $88.9 \%$ has been directed at Sub-Saharan Africa. ${ }^{8}$

The official donors, which comprised 20 countries in 1960, has now become 48, including non-OECD DAC members that report to the OECD DAC. This excludes some countries like China, India, and Brazil that do not report to the DAC. ${ }^{9}$ In Africa, the non-OECD DAC, emerging donors such as China, India, Brazil, Kuwait, Saudi Arabia, Turkey and the United Arab Emirates-the so-called seven emerging donors-have been active to varying degrees for many decades. ${ }^{10}$ China, the outright biggest donor in this group, is estimated to have dispensed USD 7.1 billion in 2013, making it the sixth-largest donor in the world. ${ }^{11}$

So what does diversification of donors mean for Africa? We may start by comparing traditional donors with emerging donors. The OECD $\mathrm{DAC}$ is the mechanism that spearheads established donors' development agenda; it is the body of policy consultations and coordination and lays out principles and guidelines for its member states. Among them is the criterion for evaluating development assistance: relevance, effectiveness, efficiency, impact and sustainability. ${ }^{12}$ And the emphasis it places on aid recipients' governance is clearly enunciated. ${ }^{13}$ The basic difference between the established donor community and the emerging donors can be summed up by the words 'governance' and 'concessionality'. According to Courtney Meyer, 'the emerging donors have begun to establish a new status quo, one without policy strings attached and one which focuses on infrastructure, innovation, exports and health, rather than governance. ${ }^{14}$

Among the emerging donors, China is the most important provider of aid to Africa that resembles ODA provided by the OECD DAC, 
and according to one study, China's share represented about $76 \%$ of the total commitments from the seven emerging donors for Africa over the period from 2003 to 2012. ${ }^{15}$ Hence, the role of China's aid to Africa and its implications on the current aid architecture in Africa will be an interesting and noteworthy theme of Africa's development. There is a need to view the relationship between traditional donors and emerging donors in terms of possible partnership, but basically the relationship is seen as being competitive. Yet, in reality, they can be complementary in nature, even enabling some kind of division of labour. But forging a meaningful and systemic collaboration between the two donor groups, while ideal, would be not so likely, at least in the near future, for the following reasons: (1) political and strategic calculations; (2) a technical logjam; and (3) inherent limitations in the capacity of recipient countries. However, some degree of de facto division of labour can emerge, given the basic differences in their fields of assistance.

From the traditional donors' perspective, their aid 'leverage' towards African countries could be curtailed if countries like China, which pursues a fundamentally different aid approach compared to the OECD DAC, provides African countries with an alternative to traditional donors' aid. Some leaders even express publicly that the West's support mostly goes into 'consumptive' areas that do not yield sustainable economic benefits and want Western countries to invest more in infrastructure building like China. Many Sub-Saharan Africans admit that their leaders have been trying to play the West off against other non-Western players to elicit as much benefit from all these countries as possible.

How much commonality in substance will the BRICS countries find with one another and whether BRICS will prevail as a coherent and forceful body wielding influence on the global stage is still uncertain. This is true because China, India, Russia, Brazil and South Africa all derive their economic power and status from their links with the global economic system in which the Western world is dominant; furthermore, these countries' interests and positions could diverge more than converge when it comes to regional and international politics.

The 10th BRICS summit that was held in July 2018 in South Africa gathered many African heads of state as the host, South Africa, was promoting BRICS-Africa business and investment. The summit was held 
under the theme: 'BRICS in Africa: Collaboration for Inclusive Growth and Shared Prosperity in the Fourth Industrial Revolution'. As expected, China's investment charm offensive highlighted the event, along with the call for free trade and multilateralism by the participants. Many African leaders voiced their wish to collaborate with BRICS for employment opportunities for the youth, industrialization and infrastructure development.

The traditional donors, in principle, may want to espouse China and draw it closer to the OECD DAC framework. However, considering China's strategic stance in Africa as well as its foreign policy orientations, I see little reason why China would want to adapt itself to the OECD DAC regime, which essentially reflects Western values. In this sense, everyone - traditional donors, China and other emerging donors, and Sub-Saharan African countries-would all want to maintain the status quo because the current dynamics in regional aid architecture serve their interests under the given circumstances.

The 'technical logjam' that I mentioned above relate to the difficulty of coordinating aid policy among donors. Given that aid coordination is difficult enough among the OECD DAC members, we can only imagine how challenging will it be to coordinate both the OECD DAC members and emerging donors. The third element, 'inherent limitations in the capacity of recipient countries', is another reason why concerted action or coordination between traditional donors and emerging donors will not easily occur. Donors do not simply give away aid and African countries do not simply take aid as it comes. Both sides have to work out arrangements and plans, and follow procedures. If the two groups were to engage in some sort of consultation or coordination mechanism with regard to aid plans for Africa, naturally, aid recipient African countries would have to be brought on board as well.

ODA is here to stay, despite all the criticisms it has attracted. Considering the trend and the demand of African countries, in all likelihood, the amount of global ODA will continue to increase for the foreseeable future, barring extraordinary circumstances like a drastic downturn in the global economy. The proliferation of donors means that while it would be difficult to establish formal coordination mechanisms among donors, nonetheless, some kind of donor 
'inter-connectivity' could emerge across the board, leading to a de facto 'division of labour' among donors.

The growth of donors and inter-connectivity or inter-dependence among various donors or donor groups also needs to be considered. There is no denying that today's engine for economic growth is global free trade and investment, and that the rise of emerging economies is attributable to them being closely integrated into the global economy. Different countries with different political regimes may have different ways of running their economies, but the universal ticket to national pre-eminence depends on wealth creation and this can only come by actively engaging in global economic transactions.

In this regard, China draws our attention in light of its perceived growing influence and assertiveness on the global stage and especially its aggressiveness in advancing into African markets. Is China a rival, a potential threat to the existing development norm and order or can it be a benign force, a constructive partner of traditional donors? Economically, China's growth has been possible by taking advantage of the global market economy, and many countries have also benefited from China's economic power. The trend seems to be that China is economically increasingly linked to the world. When I visited the Brookings Institute in July 2009, I found an interesting book entitled Power and Responsibility in its bookstore. This book advocated resurrecting US global leadership by building partnerships and institutions for cooperation with traditional and emerging powers, mindful, as the authors pointed out, that rising powers such as China 'recognize that their economic growth relies on a strong and resilient international and finance system'. ${ }^{16}$

With respect to China's economic rise, the principal architects of US foreign policy at that time seemed to have concluded that there was no cause for concern as long as China was integrated into the prevailing international regimes. Their logic was that the US might no longer be the hegemonic superpower it once was, but that it has sufficient power to lead the world through smart multilateralism. This seems to be the correct perspective. Joseph Nye asserts in his book Is the American Century Over? that the US will remain the strongest power in the world, with no visible sign that its status will be altered in the foreseeable 
future. He recognizes that China poses the biggest challenge to the US, but China still lags considerably behind it in the three aspects of power: military, economic and soft power. ${ }^{17}$

On the third point that there should be a division of labour among donors, we should see this from the standpoint of international collaboration and coordination, being mindful of the difference in the 'lifetime experiences' of donors. To a certain extent, this is already happening in a natural way, as donors would have certain areas of expertise that they would wish to impart to developing countries.

\section{Notes}

1. Yemi Lalude, 'There Is Huge Entrepreneurial Energy in Africa; How Do We Harness It?', in 'Opinion', The East African (weekly newspaper), 6-12 May 2017, p. 15.

2. Harry Boyte, 'Conversations on Democracy—The John Dewey Society and Civic Studies', Huffpost (blog), 27 April 2016, https://www.huffingtonpost.com/harry-boyte/conversations-on-democrac_b_9776550. html?guccounter $=1$.

3. Erik Thorbecke, 'The Evolution of the Development Doctrine and the Role of Foreign Aid, 1950-2000,' in Fin Tarp (ed.), Foreign Aid and Development: Lessons Learnt and Directions for the Future (London: Routledge, 2000), pp. 17-45.

4. The 17 SDGs are: (Goal 1) end poverty in all its forms everywhere; (Goal 2) end hunger, achieve food security and improved nutrition and promote sustainable agriculture; (Goal 3) ensure healthy lives and promote wellbeing for all at all ages; (Goal 4) ensure inclusive and equitable quality education and promote lifelong learning opportunities for all; (Goal 5) achieve gender equality and empower all women and girls; (Goal 6) ensure availability and sustainable management of water and sanitation for all; (Goal 7) ensure access to affordable, reliable, sustainable and modern energy for all; (Goal 8) promote sustained, inclusive and sustainable economic growth, full and productive employment and decent work for all; (Goal 9) build resilient infrastructure, promote inclusive and sustainable industrialization and foster innovation; (Goal 10) reduce inequality within and among countries; (Goal 11) make cities and human settlements inclusive, safe, resilient and sustainable; 
(Goal 12) ensure sustainable consumption and production patterns; (Goal 13) take urgent action to combat climate change and its impacts; (Goal 14) conserve and sustainably use the oceans, seas and marine resources for sustainable development; (Goal 15) protect, restore and promote sustainable use of terrestrial ecosystems, sustainably manage forests, combat desertification, and halt and reverse land degradation and halt biodiversity loss; (Goal 16) promote peaceful and inclusive societies for sustainable development, provide access to justice for all and build effective, accountable and inclusive institutions at all levels; (Goal 17) strengthen the means of implementation and revitalize the global partnership for sustainable development.

5. Kang Seonjou, 'Adoption of Post-2015 Sustainable Development Goals (SDGs) and its Implications for Development Cooperation Diplomacy', International Analysis, No. 2015-29 (23 October 2015), Institute of Foreign Affairs and National Security, Republic of Korea (Korean).

6. 'What have the millennium development goals achieved?', The Guardian, 6 July 2015. The UN released the final assessment of MDGs on 6 July 2015 (http://www.un.org/millenniumgoals/2015_MDG_ Report/pdf/MDG\%20report\%202015\%20presentation_final.pdf).

7. The term 'Samaritan's dilemma' was coined by the economist James M. Buchanan. See James M. Buchanan, 'The Samaritan's dilemma', in E.S. Phelps (ed.), Altruism, Morality and Economic Theory (New York: Russell Sage Foundation, 1975), pp. 71-85.

8. 'Aid spending by Development Assistance Committee (DAC) donors in 2016', Development Initiatives, 12 April 2017, http://devinit.org/ post/aid-spending-by-development-assistance-committee-dac-donors-in-2016.

9. 'The rise of new foreign aid donors: why does it matter?', Devpolicyblog, 4 August 2017, http://devpolicy.org/rise-new-foreignaid-donors-matter-20170804.

10. Of seven emerging donors, China's ODA-like aid represented about $76 \%$ of the total of this group over the period from 2003 to 2012, according to the EU Commission's paper 'The European Union, Africa and New Donors: Moving Towards New Partnership', Highlights (2015). Monday, 11 May. https://ec.europa.eu/europaaid/sites/devco/ files/com-411-africa-final_highlights_11052015_en.pdf. 
11. 'Estimating China's Foreign Aid 2001-2013', Working Paper, JICA-RI, JICA USA May/June 2014, https://www.jica.go.jp/usa/english/office/ others/newsletter/2014/1405_06_02.html.

12. The DAC Principles for the Evaluation of Development Assistance, OECD (1991).

13. http://www.oecd.org/dac/accountable-effective-institutions.

14. Courtney Meyer, 'Emerging Donors: Ushering in a New Aid Era?', Think Africa Press, 25 July 2012.

15. EU, 'The European Union, Africa and New Donors: Moving Towards New Partnership', 2015.

16. Bruce D. Jones, Carlos Pascual, and Stephen John Stedman, Power and Responsibility: Building International Order in an Era of Transnational Threats (Washington, DC: Brookings Institution Press, 2009), p. 23.

17. Joseph S. Nye, Jr., Is The American Century Over? (Malden: Polity Press, 2015).

Open Access This chapter is licensed under the terms of the Creative Commons Attribution 4.0 International License (http://creativecommons. org/licenses/by/4.0/), which permits use, sharing, adaptation, distribution and reproduction in any medium or format, as long as you give appropriate credit to the original author(s) and the source, provide a link to the Creative Commons license and indicate if changes were made.

The images or other third party material in this chapter are included in the chapter's Creative Commons license, unless indicated otherwise in a credit line to the material. If material is not included in the chapter's Creative Commons license and your intended use is not permitted by statutory regulation or exceeds the permitted use, you will need to obtain permission directly from the copyright holder.

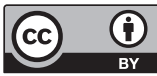

